\title{
Interpretation of the Association between Beta-Blockers and Hip/Femur Fracture
}

\author{
Frank de Vries $^{\mathrm{a}-\mathrm{c}}$ Patrick Souverein ${ }^{\mathrm{a}}$ \\ a Department of Pharmacoepidemiology and Clinical Pharmacology, Utrecht Institute for Pharmaceutical \\ Sciences, Utrecht University, Utrecht, and ${ }^{\text {b}}$ Department of Clinical Pharmacy and Toxicology, Maastricht University \\ Medical Centre+, Maastricht, The Netherlands; ${ }^{C}$ MRC Epidemiology Resource Centre, University of Southampton, \\ Southampton, UK
}

Dear Sir,

In a recent publication on the effects of carvedilol and low-turnover bone disease, Dr. Goto and colleagues have cited our work $[1,2]$. They wrote that 'we have suggested that use of beta-blockers is associated with a reduced risk of fractures' [1]. We are afraid that this does not reflect the key finding of this study: although we observed a small inverse association between beta-blocker use and risk of hip/femur fracture in Dutch and British patients, it is unlikely that this effect was causal: 'the effect was constant with cumulative dose and the odds ratio [between beta-blocker use and hip/femur fracture risk, FV] was below 1.0, even among patients who had just started treatment with beta-blockers. As the mechanism by which beta-blockers could influence BMD is likely to need some time to exert a clinically relevant effect, this finding suggests that the association between beta-blockers and fracture risk is not causal' [2]. Although our study was conducted 5 years ago, we are not aware of any additional strong evidence which justifies a different interpretation of those findings.

\section{Disclosure Statement}

The Department of Pharmacoepidemiology and Clinical Pharmacology, Utrecht Institute for Pharmaceutical Sciences, employing authors Frank de Vries and Patrick Souverein, has received unrestricted funding for pharmacoepidemiological research from GlaxoSmithKline, Novo Nordisk, pri- vate-public funded Top Institute Pharma (www.tipharma.nl and includes co-funding from universities, government and industry), the Dutch Medicines Evaluation Board and the Dutch Ministry of Health.

\section{References}

-1 Goto S, Fujii H, Kono K, Nakai K, Hamada Y, Yamato H, Shinohara M, Kitazawa R, Kitazawa S, Nishi S, Fukagawa M: Carvedilol ameliorates low-turnover bone disease in non-obese type 2 diabetes. Am J Nephrol 2011;34:281-290.

-2 de Vries F, Souverein PC, Cooper C, Leufkens HG, van Staa TP: Use of beta-blockers and the risk of hip/femur fracture in the United Kingdom and The Netherlands. Calcif Tissue Int 2007;80:69-75.

\section{KARGER}

Fax +4161306 1234 E-Mail karger@karger.ch www.karger.com
Dr. F. de Vries

Utrecht Institute for Pharmaceutical Sciences, Utrecht University

Universiteitsweg 99

NL-3584 Utrecht (The Netherlands)

Tel. +31 30253 7324,E-Mail f.devries@uu.nl 


\section{Reply \\ Shunsuke Goto Hideki Fujii \\ Division of Nephrology and Kidney Center, Kobe University Graduate School of Medicine, Kobe, Japan}

We appreciate the interest of Dr. de Vries and Dr. Souverein in our report. We believe they have concluded that an association between beta-blockers and fracture risk is not causal, although they observed a small inverse association between the use of beta-blockers and the risk of hip/femur fractures. We have cited seven papers [1-7] that suggest that the use of beta-blockers is associated with a reduced risk of fractures. These papers, except for their paper, concluded that treatment with beta-blockers is associated with a reduced risk of fractures. However, as they have mentioned, the evidence is limited because all of these are observational studies. Therefore, to clarify the clinical effect of beta-blockers on fractures in humans, large randomized controlled trials that include fracture as an endpoint should be conducted.

\section{References}

1 Schlienger RG, Kraenzlin ME, Jick SS, Meier CR: Use of $\beta$-blockers and risk of fractures. JAMA 2004; 292:1326-1332.

2 Rejnmark L, Vestergaard P, Mosekilde L: Treatment with $\beta$-blockers, ACE inhibitors, and calcium-channel blockers is associated with a reduced fracture risk: a nationwide case-control study. J Hypertens 2006;24: 581-589.

- 3 Pasco JA, Henry MJ, Sanders KM, Kotowicz MA, Seeman E, Nicholson GC: Beta-adrenergic blockers reduce the risk of fracture partly by increasing bone mineral density: Geelong Osteoporosis Study. J Bone Miner Res 2004;19:19-24.

-4 Meisinger C, Heier M, Lang O, Döring A: Beta-blocker use and risk of fractures in men and women from the general population: the MONICA/KORA Augsburg cohort study. Osteoporos Int 2007;18:1189-1195.
5 Bonnet N, Gadois C, McCloskey E, Lemineur G, Lespessailles E, Courteix D, Benhamou CL: Protective effect of $\beta$-blockers in postmenopausal women: influence on fractures, bone density, micro- and macroarchitecture. Bone 2007;40:1209-1216.

-6 De Vries F, Souverein PC, Cooper C, Leufkens HG, van Staa TP: Use of $\beta$-blockers and the risk of hip/femur fracture in the United Kingdom and The Netherlands. Calcif Tissue Int 2007;80:69-75.

7 Gage BF, Birman-Deych E, Radford MJ, Nilasena DS, Binder EF: Risk of osteoporotic fracture in elderly patients taking warfarin: results from the National Registry of Atrial Fibrillation 2. Arch Intern Med 2006;166: 241-246. 